Dikirim: 15 Desember 2017 Diterbitkan: 1 Februari 2018

\section{Pengalaman ibu menghadapi remaja dengan gejala premenstrual dysphoric disorder}

\section{Mothers experience dealing an adolescent with premenstrual dysphoric disorder symptoms}

Tri Kesuma Dewi ${ }^{1}$, Purwanta Purwanta ${ }^{2}$, Elsi Dwi Hapsari ${ }^{1}$

\begin{abstract}
Purpose: The purpose of this study is to explore mothers experience dealing an adolescent with symptoms of premenstrual dysphoric disorder (PMDD). Method: The research used quantitative and qualitative methods. In the quantitative method used with cross sectional design using the PMDD symptom questionnaire according to DSM-IV in adolescents, while in qualitative method using in-depth interview technique on the mother of adolescent. Data analysis on quantitative method using descriptive analysis while on qualitative using method of data analysis Colaizi (1973). Results: This study showed that $23 \%$ adolescents had PMDD symptoms and found five themes: 1) the mother knew and felt the symptoms of PMDD experienced by the child, 2) The attitude and the limited time of mother and child affected the delivery of PMDD symptoms of the child to the mother, 3 ) Diversity of the mother's response when the child is facing symptoms of PMDD , 4) The handling that the mother gives to the child when the child has PMDD symptoms is sourced from the past, 5) Mother seeks information about the handling that can be done when experiencing PMDD symptoms. Conclusion: Mothers play an important role in helping adolescent deal with PMDD symptoms. Mothers can provide support, be it instrumental support, assessment, emotional and informational. Mothers should have adequate knowledge of PMDD symptoms so that the support provided can be maximized.
\end{abstract}

Keywords: the role of mother; adolescent; premenstrual dysphoric disorder

\footnotetext{
${ }^{1}$ Departemen Keperawatan Anak dan Maternitas, Fakultas Kedokteran, Universitas Gadjah Mada (Email: trikesumadewi06@gmail.com)

${ }^{2}$ Departemen Keperawatan Jiwa dan Komunitas, Fakultas Kedokteran, Universitas Gadjah Mada
} 


\section{PENDAHULUAN}

Yogyakarta memiliki lebih dari 180 ribu pelajar berusia remaja (1). Remaja mengalami perubahan baik secara fisik maupun psikologis, salah satu perubahan yang terjadi pada remaja putri adalah mengalami menstruasi. Beberapa wanita mengalami menstruasi dengan berbagai gangguan, seperti gejala pramenstruasi atau Premenstrual sydrome (PMS). Wanita yang mengalami gejala pramenstruasi yang parah disebut sebagai Premenstrual Dysphoric Disorder (PMDD). Gejala yang terjadi antara lain perubahan suasana hati yang berat atau timbul rasa marah, kelelahan, depresi, kecemasan dan penarikan diri dari hubungan sosial (2). Angka PMDD di China sebesar 2,1\% dengan jumlah 954 responden sedangkan di Yordania angka PMDD mencapai 10,26\% (3,4). Penyebab gejala belum diketahui secara pasti, namun beberapa penelitian menyebutkan bahwa gaya hidup, genetik, aktivitas fisik dan stres merupakan sebagai faktor yang berpengaruh (5). Premenstrual Dysphoric Disorder berpengaruh pada kualitas hidup remaja, karena memengaruhi fungsi fisik, status kesehatan, fungsi sosial, status emosional, vitalitas dan kesehatan mental (6). Berbagai penanganan yang dapat dilakukan untuk mengurangi dampak dari gejala adalah penanganan farmakologi dan non-farmakologi. Salah satu penanganan non-farmakologi yang dapat dilakukan adalah memberikan dukungan sosial. Dukungan sosial yang paling penting adalah dukungan sosial yang bersumber dari orang terdekat, salah satunya dukungan ibu. Penelitian terkait dukungan ibu selama anak mengalami gejala belum pernah dilakukan, untuk itu perlu dilakukan penelitian untuk melihat apakah dukungan yang telah diberikan ibu kepada anak berjalan dengan optimal.

\section{METODE}

Penelitian ini menggunakan metode penelitian kuantitatif dan kualitatif. Metode penelitian kuantitatif dilakukan dengan pendekatan cross-sectional. Populasi pada metode kuantitatif adalah seluruh siswi kelas 2 SMA di Yogyakarta. Sampel adalah seluruh siswi kelas 2 di SMA 10, Budya Wacana dan SMA Muhammadiyah 3 yang berjumlah 233 orang dengan kriteria inklusi bersedia menjadi responden, diizinkan sekolah dan diberikan izin oleh orang tua. Kriteria ekslusi adalah siswi yang tidak hadir saat pengambilan data. Metode kuantitatif digunakan untuk mengetahui prevalensi siswi yang mengalami gejala, sehingga peneliti dapat mengetahui ibu yang menjadi partisipan. Metode kualitatif dilakukan menggunakan pendekatan fenomenologi. Populasi adalah seluruh ibu yang memiliki anak remaja dengan gejala berdasarkan hasil analisis data kuantitatif berjumlah 52 orang, dengan kriteria inklusi adalah ibu yang memiliki anak dengan gejala, bersedia menjadi partisipan, dan tinggal serumah dengan anak. Sedangkan kriteria ekslusi adalah ibu yang memiliki gangguan dalam ber- komunikasi. Partisipan penelitian berjumlah 6 orang. Teknik pengambilan data dilakukan dengan wawancara semistruktur. Penelitian dilakukan di Yogyakarta pada tanggal 25 April-21 Juli 2017.

Partisipan adalah ibu dengan kriteria inklusi: memiliki anak dengan gejala serta tidak mengalami gangguan berkomunikasi. Penentuan gejala dilakukan dengan menggunakan kuesioner baku DSM-IV yang di translasi oleh Hapsari (2006) (7). Kriteria gejala adalah mengalami minimal 5 gejala, yang 1 diantaranya adalah gejala afektif, dan gejala tersebut mengganggu aktivitas sehari-hari dan mengganggu hubungan keluarga dan teman. Analisis data kuantitatif menggunakan SPSS versi 21, untuk mengetahui jumlah siswi yang mengalami gejala. Proses analisis data kualitatif menggunakan analisis data Colaizzi. Triangulasi dilakukan kepada 3 siswi, guru dan perawat di sekolah. Alat bantu yang peneliti gunakan adalah alat perekam dan catatan lapangan.

\section{HASIL}

Tabel 1 menunjukkan distribusi gejala yang dialami siswa berdasarkan hasil skrinning terhadap 226 siswi.

Tabel 1. Distribusi siswa berdasarkan gejala

\begin{tabular}{|c|c|}
\hline Kategori & $\begin{array}{c}\text { Jumlah (\%) } \\
\mathrm{N}=226\end{array}$ \\
\hline Gejala PMS & 40,3 \\
\hline Gejala PMDD & 23,0 \\
\hline Non gejala PMS/PMDD & 36,7 \\
\hline Total & 100 \\
\hline
\end{tabular}

Penentuan sampel pada tahap kualitatif menggunakan teknik sampel variansi maksimun. Karakteristik partisipan dapat dilihat pada tabel 2. 
Tabel 2. Karakteristik Partisipan

\begin{tabular}{|c|c|c|c|c|c|c|c|}
\hline $\mathbf{P}$ & Umur & $\begin{array}{c}\text { Status } \\
\text { pernikahan }\end{array}$ & Jumlah anak & Suku & Agama & Pekerjaan & $\begin{array}{c}\text { Pendidikan } \\
\text { terakhir }\end{array}$ \\
\hline P1 & 45 tahun & Cerai Hidup & $\begin{array}{l}1 \text { perempuan } \\
1 \text { laki-laki }\end{array}$ & Jawa & Islam & Wiraswasta & S1 \\
\hline $\mathrm{P} 2$ & 47 tahun & Menikah & $\begin{array}{l}4 \text { perempuan } \\
2 \text { laki-laki }\end{array}$ & Jawa & Islam & $\begin{array}{l}\text { Ibu Rumah } \\
\text { Tangga }\end{array}$ & SMA \\
\hline P3 & 44 tahun & Cerai mati & 1perempuan & Jawa & Kristen & Wiraswasta & SMA \\
\hline P4 & 44 tahun & Menikah & $\begin{array}{l}\text { 1perempuan } \\
1 \text { laki-laki }\end{array}$ & Jawa & Islam & Guru & S1 \\
\hline P5 & 38 tahun & Menikah & 2 perempuan & Jawa & Islam & $\begin{array}{l}\text { Ibu Rumah } \\
\text { Tangga }\end{array}$ & SMA \\
\hline P6 & 46 tahun & Menikah & 2 perempuan & Jawa & Islam & Wiraswasta & SMA \\
\hline
\end{tabular}

Ibu mengetahui keluhan menstruasi anak secara fisik dan emosional. Partisipan mengetahui dan merasakan keluhan gejala yang anak alami, secara fisik dan emosional. Pada gejala fisik anak melaporkan keluhan yang dialami kepada ibu, sedangkan untuk gejala afektif hal ini dapat ibu rasakan bahwa anak mengalami perubahan perilaku dan perubahan emosi selama periode sebelum dan beberapa hari menstruasi, hal ini dapat dilihat dari ungkapan beberapa partisipan.

"Ya paling itu.. agak pusing.. pusingnya darahnya turun.. ya cuma sekedar fisik aja.. paling sakit perut.. paling nanti bilang “ agak agak pusing ma” ya sudah nanti buat rehat.. (P1,45 tahun).

"Kakinya kemeng-kemeng kabeh, ya itu cuman kayak gitu.. iya, "aku kakinya sakit ma" "ya udah dikasih bantal dibawah kaki” (P3, 44 tahun).

"Ya,.. sering.. kalo marah-marah itu.. ya dia itu Cuma kalo marah-marah dia itu kalo di panggil suaranya sering atos dia itu.. dia jarang ini sih.. sering ngambek itu aja”(P5, 38 tahun).

Ibu mengetahui dan merasakan bahwa gejala yang dialami anak tidak hanya mengganggu aktivitas sehari-hari, tetapi berhubungan dengan orang lain.

“...Kalo disekolah saya Tanya "kalo disekolah kamu kayak gitu gak?” "iyalah, kadang sama temenku pengen ngamuk aja, tapi aku diem” haha.. sensi katanya “ daripada Jawab aku juga gondok, ya sudah aku diem aja” gitu katanya.”. (P1, 45 tahun)

"Dampaknya apa ya.. nganu ya paling terganggu.. belajar aja males cuman pengennya tidur aja dia” (P6, 46 tahun).

Penentu tersampaikan keluhan menstruasi kepada ibu. Didapatkan hasil bahwa tidak semua anak menyampaikan keluhan fisik menstruasi yang dialami kepada ibu.
“Gak pernah... gak pernah ngeluh sama sekali, dia ketika menstruasi, ketika haid itu tidak pernah mengeluh apa-apa, ya cuek aja dia”. (P2, 47 tahun)

"Aktif anaknya itu jadi dia gak pernah ngeluh itu.. sakit.. saya kurang tau kalo dia merasakan atau tidak merasa”. (P4, 44 tahun)

Berdasarkan hasil analisis, terlihat bahwa beberapa faktor yang dapat memengaruhi tersampaikan keluhan fisik anak selama periode sebelum dan saat menstruasi adalah, karakter dan persepsi anak tentang keluhan fisik yang dialami serta keterbatasan waktu antara ibu dan anak. Pada anak yang tidak menceritakan keluhan fisik yang dialaminya, ibu merasa bahwa anak memiliki karakter yang pendiam

"Mungkin karena anaknya pendiem ya mbak, jadi saya juga kurang tahu” (P4, 44 tahun).

Terlihat bahwa persepsi yang menyebabkan anak tidak menyampaikan keluhan menstruasi karena anak merasa bahwa keluhan fisik yang dialami adalah sebuah hal yang biasa dan merasa bahwa keluhan menstruasi cukup ditangani sendiri dengan menahan rasa nyeri yang dialami.

“Aku gak pernah bilang sama umi karena aku udah paham kalo aku mens mesti kayak gitu” (Anak P2, 17 tahun)

"Soalnya masih bisa ditahan, kalo udah gak bisa ditahan baru bilang” (Anak P4, 17 tahun)

Faktor lain yang menjadi penentu tersampaikan keluhan menstruasi anak kepada ibu adalah ketersediaan waktu, kesibukan anak dan ibu membuat waktu bertemu antara anak dan ibu berkurang, sehingga memungkinkan keluhan menstruasi yang dialami anak terhambat.

"Mbak kiki kegiatannya udah banyak, saya juga pulangnya magrib, ayahnya juga magrib mungkin kita kalo ketemu ya cuman itu tadi makan malem, ngobrol, 
ya becanda-becanda aja, jadi tidak.. tidak.. kita belum pernah.. saya belum tau kalo disekolah sama temen-temennya, dia merasakan itu kita belum tau” (P4, 44 tahun)

Hal ini diperkuat dengan kesibukan yang ibu sehari-hari.

"Kalo saya di paud dari pagi, sekitar jam 7 atau 8 sampe jam 5, itu kalo gak ada kegiatan.. pelatihan, tapi nanti kalo ada pelatihan sampe malam bisa, tergantung ngisi pelatihannya sih, trus kalo disekolah itu sebenrnya kerjanya gak terlalu banyak gitu tapi banyak diluarnya gitu , misalnya harus ngisi pelatihan digunung kidul, di kulon progo perjalanannya seperti itu” (P4, 44 tahun)

\section{Keberagaman respon ibu saat menghadapi keluhan}

fisik dan psikologis anak. Saat anak mengalami gejala fisik dan menyampaikan kepada ibu, maka ibu akan berusaha untuk membantu anak mengurangi gejala fisik. Respon ibu saat anak mengalami gejala fisik adalah memberikan pertolongan langsung dan memberikan saran kepada anak.

“...trus nanti " mama, sakit ma” udah cuman minum tak bikinin itu, kunyir asem itu”

"kalo sakit ya saya dikasih minyak atau kunyir asem" (P3, 44 tahun)

Berbagai saran yang diberikan ibu kepada anak saat anak mengalami keluhan fisik menstruasi antara lain menyarankan anak untuk tidur, makan yang cukup, tidak minum es, minum minuman hangat, banyak mengonsumsi air putih dan menyarankan anak menaruh bantal untuk menyangga kaki, apabila kaki merasa pegal, selain itu ibu menyarankan anak untuk menerima keluhan menstruasi yang dialami.

"Ngomong.. iya.. dia itu apa ya.. kalo untuk sakit lebih rewel dia..lebih banyak ngeluh.. ngeluh..kalo adeknya kan gak.. diem aja.. kalo dia gak.. kadang "pusing ah”.. kamu itu kok kadang banyak ngeluh..” (P1, 45 tahun)

"Nek ndak biasanya dia langsung, sekarang badan sakit, sesok turnamen" "sakit ya nikmatin aja”

"Aduh ma, besok turnamen futsal, hari ini gimana? "Iha mosok mau ditunda wong kamu itu gak usah di gon alasan kayak gitu, karena nanti selamanya kayak gitu sampe kamu dewasa itu mengalami seperti ini, kayak gitu” (P3, 44 tahun)
“.. paling yo cuman gitu aja, yo cuman de `e marah tanpa sebab, nah aku marah yo.. kadang gitu, kadang tanpa sadar toh mbak kayak gitu”

Respon yang disampaikan oleh partisipan diperkuat dengan hasil triangulasi pada anak.

"Mama diemin aja, ya udah dek dirasain aja udah kodratnya jadi cewek, kalo gak nanti tak cariin jamu atau gak tak buatin jamu.. gitu” (Anak P3, 17 tahun).

Penanganan ibu pada anak saat mengalami keluhan menstruasi bersumber dari masa lalu. Tema keempat ditemukan bahwa penanganan atau pertolongan yang ibu berikan kepada anak bersumber dari masa lalu adalah berasal dari pengalaman yang ibu alami.

"Saya.. iya.. , saya malah lebih parah.., kadang saya itu sampe pingsan.. sangking sakitnya. Di SMA itu sering... pokoknya, pas itu keluar, saya pas posisi disekolah.. udah jadi pasien.. dibawa pulang.. udah gak bisa ngapa-ngapainlah. Sering kayak gitu.. pokoknya hari pertama kayaknya drop semuanya” (P1, 45 tahun).

"Kalo saya keluhannya Cuma waktu itu payudara sakit, tapi setelah menikah malah biasa juga.. enggak yang gitu, paling jerawat” (P2, 46 tahun).

“Gak, waktu remaja ya.. remaja itu paling nyeri perut ya.. Iya, kalo mau mens itu, seminggu sebelumnya migren gitu.. biasa.. saya bawa kedokter itu ndak papa.. karena memang siklus mens itu seperti itu..” (P3, 44 tahun).

"Ehm.. kalo saya pusing, pegel perut ini kayak sakit dikit lho.. gak sakit yang sakiiit.. gak.. cuman kayak mules itu” (P6, 46 tahun).

Penanganan yang ibu lakukan beragam mulai penanganan non-farmakologi seperti tidur, makan teratur dan minum air putih, kerokan, minum susu dan mengoleskan minyak kayu putih pada bagian yang sakit. penanganan farmakologi yang ibu lakukan selama mengalami keluhan fisik dengan minum jamu, susu, minum obat sakit kepala, obat penambah darah, paracetamol dan mendapatkan suntikan anti nyeri.

"Ya.. paling sama ibu saya itu.. dikasih kunyir asem.. saya rehat cukup, nanti hari kedua dah bagus..” (P1, 45 tahun) 
"Ya kalo saya cuman anu, mengatasinya gak minum obat enggak.. cuman kita nganu.. makan teratur, makan teratur terus minum air putih banyak gitu" (P6, 46 tahun)

"Kalo saya biasanya cuman minum susu, kalo aku susunya apa aja, biasanya yang gambarnya panda itu .. bear.. pa itu atau kalo gak indomilk.. indomilk juga gak papa

"Gak tau ya, saya juga gak berani minum obat itu, kalo sangat nyeri sekali biasanya sampe nyeri sekali gitu.. biasanya dibawa aja ke kimia farma, dikasih suntikan anti nyeri gak tau .. tapi ya jarang juga kalo memang terlalu banyak itu, tapi kalo enggak ya enggak saya cuman dirumah rebahan, pulang kerja paling minum susu, dibuat tidur aja, saya kasih minyak-minyak itu nanti ilang sendiri mbak..” (P4, 44 tahun)'

"Saat aku berkeluhan, jadi kalo misalnya lagi mau mens itu sudah pusing gitu, aku minum sangobion.. kalo pas saat men situ saya gak merasa pusing, biasa aja gitu saya gak minum" (P5, 38 tahun)

Ibu berusaha mencari informasi penanganan keluhan menstruasi. Selain mendapatkan informasi yang bersumber dari pengalaman, ibu berusaha mencari informasi tentang penanganan yang dapat dilakukan saat anak mengalami gejala pada orang-orang terdekat seperti orang tua, teman dan saudara kandung, serta berkonsultasi dengan tenaga kesehatan seperti dokter.

"Huum mbak.. Tanya kakak.. kan gak tau aku, nanti besok ini setelah menstruasi abis.. berenti nanti minum ini jamu, gak diharuskan minum obat enggak.. ibu saya biasanya minum jamu kita.. nek gak beras kencur, kunyit asem.." (P6, 46 tahun)

"Kalo temen biasanya kasih tau.. coba ini.. coba ini.. gitu, ya kalo kita nyoba itu kalo cocok sama badan kita mungkin, gak papa gak ada efek kan.. tapi tiap badan orang kan beda-beda" (P1, 45 tahun)

"Kalo orang tua dulu itu bilang nya kalo sakit pada saat mens itu, masuk angina jadi harus dikerok.. jadi intinya po men paling gak banyak angin nya ya gak bisa keluar karena badan itu kaku apa ya.. jadi membuat ketegangan-ketegangan dibagian tubuh tertentu dan kalo bisa dikerok.. kalo sudah dikerok itu rasane lega.. terus itu nyaranin minum obat.. kalo pusing minum obat pusing, kayak gitu kalo orang tua dulu" (P5, 38 tahun)
"Sudah.. kalo kata dokter itu masih wajar.. dan kalo gak mens aku enggak itu mbak..” (P3, 44 tahun)

"Saya browsing sendiri yang kira-kira jamu herbal gak ada efeknya ya itu tak coba. Cuman gak terus-terus gak.. pas sakit aja" (P1, 45 tahun)

\section{BAHASAN}

Jumlah remaja yang mengalami gejala pada penelitian ini lebih banyak dibandingkan dengan penelitian yang dilakukan oleh Marfuah (8) yang menyebutkan bahwa jumlah remaja yang mengalami gejala adalah sebesar 9\%. Perbedaan prevalensi remaja dikarenakan perbedaan lokasi penelitian. Gejala yang dialami oleh remaja yang tinggal di daerah perkotaan lebih tinggi dibandingkan di pedesaan. Remaja perempuan yang tinggal di kota besar berisiko mengalami sindrom menstruasi 3 kali lebih besar dibandingkan remaja yang tidak tinggal di kota besar (9). Remaja di perkotaan lebih banyak mengalami sindrom menstruasi (76\%) dibandingkan dengan remaja di pedesaan $(56,6 \%)(10)$.

Ibu merasakan keluhan menstruasi anak secara fisik dan emosional. Gejala fisik yang anak laporkan kepada ibu berupa sakit perut, nyeri payudara, tidak enak badan (merasa seperti demam), sakit pinggang, pegal pada kaki dan pusing,sedangkan gejala afektif yang ibu rasakan saat anak akan menstruasi dan beberapa hari setelah menstruasi adalah perubahan perilaku seperti pola makan, pola tidur, dan emosi. perubahan emosi yang terjadi adalah anak lebih mudah marah dan cepat tersinggung.

Menurut The American Congress of Obstetricians and Gynecologist (ACOG), tanda dan gejala PMDD terdiri dari keluhan somatik dan keluhan afektif. Keluhan somatik berupa nyeri kepala, nyeri payudara, nyeri kembung, nyeri persendian dan pembengkakan ektremitas. Keluhan afektif yang dapat dialami adalah depresi, ledakan kemarahan, iritabilitas, kecemasan, kebingungan dan penarikan diri secara sosial (11). Gejala utama yang dirasakan saat mengalami sindrom menstruasi berat adalah keram perut dan nyeri persendian (12).

Penelitian ini menunjukkan beberapa ibu merasakan gejala afektif pada anak berupa peningkatan emosi. Wanita yang mengalami gejala PMDD akan memiliki tingkat emosi yang lebih tinggi dan kontrol emosi yang rendah (13,14). Penelitian ini menunjukkan gejala yang timbul dapat mengganggu aktivitas harian dan hubungan sosial anak. PMDD dapat memengaruhi 
fungsi fisik, tubuh, status kesehatan secara umum, fungsi sosial dan emosional $(15,16)$.

Penentu penyampaian keluhan menstruasi pada ibu. Hasil penelitian menemukan 2 dari 6 partisipan menyebutkan anak mereka tidak pernah menyampaikan gejala fisik yang dialami. Remaja asia menemukan dari 156 remaja 58,1\% yang menceritakan masalah seputar menstruasi kepada ibu dan 15,2\% tidak menceritakan kepada siapapun (17). Hal berbeda ditemukan pada penelitian di Amerika yang menemukan dari 76 remaja, 84\% diantaranya mendiskusikan masalah menstruasi kepada ibu, sedangkan yang lain mendiskusikan pada teman dan tenaga kesehatan (18).

Faktor yang memengaruhi penyampaian gejala fisik anak pada ibu adalah karakter dan persepsi anak tentang gejala dan faktor ketersediaan waktu. Anak yang tidak menyampaikan keluhan menstruasi pada ibu adalah anak yang memiliki karakter pendiam sedangkan pada anak yang menyampaikan keluhan menstruasi kepada ibu memiliki karakter yang lebih terbuka. Keterbukaan anak menjadi faktor penyampaian informasi tentang seksualitas termasuk masalah yang dialami anak saat menstruasi (19).

Faktor lain yang memengaruhi anak adalah persepsi tentang gejala fisik yang dialami. Anak yang tidak menyampaikan gejala fisik yang dialami memiliki persepsi bahwa gejala yang dialami adalah sebuah hal yang normal dan hanya perlu ditangani dengan menahan rasa sakit yang terjadi sehingga mereka merasa tidak membutuhkan bantuan orang lain. WHO menyebutkan terdapat empat penyebab seseorang berperilaku atau tidak berperilaku pemikiran dan perasaan yang diwujudkan dalam bentuk pengetahuan, persepsi, sikap, kepercayaan dan penilaian seseorang terhadap objek kesehatan, 2) anjuran atau larangan dari orang penting dari kelompok referensi, 3) sumber daya yang mencakup fasilitas, uang, waktu, tenaga dan sebagainya, 4) kebudayaan yang berupa perilaku normal, kebiasaan, nilai dan penggunaan sumber-sumber di masyarakat yang akan menghasilkan suatu pola hidup (20). Faktor terakhir yang dapat memengaruhi tersampaikan gejala fisik yang dialami anak kepada ibu adalah keterbatasan waktu.

Penelitian ini menemukan ibu dan anak sama-sama memiliki kegiatan padat. Kesibukan ini disebabkan karena aktivitas anak di luar jam sekolah dan ibu pekerja. Keterbatasan waktu membuat pertemuan antara ibu dan anak menjadi terbatas sehingga penyampaikan informasi terhambat. Hambatan utama dalam proses komunikasi ibu yang bekerja dengan anak adalah adanya keterbatasan waktu (21).
Keberagaman respon ibu saat menghadapi keluhan fisik dan psikologis anak. Pada saat anak mengalami keluhan fisik menstruasi dan menyampaikan kepada ibu, maka ibu akan memberikan respon yang berbeda-beda. Pada saat anak mengalami gejala fisik ibu memberikan respon pertolongan secara langsung. Pertolongan langsung yang ibu lakukan adalah dengan memberikan anak obat sesuai dengan gejala. Pada anak yang mengeluh nyeri perut ibu memberikan paracetamol dan bila anak mengeluh pusing, ibu memberikan sangobion. Selain memberikan obat-obat, ibu memberikan anak pengobatan tradisional.

Saran yang diberikan ibu saat anak saat anak mengalami gejala fisik adalah istirahat selama mengalami nyeri, makan cukup, tidak minum es, mengonsumsi minuman hangat dan menaruh bantal untuk menyangga kaki.

Respon yang diberikan ibu selama anak mengalami gejala menjadi sumber utama anak untuk melakukan penanganan saat mereka mengalami gejalat. Penelitian menunjukkan remaja etnis Melayu memiliki cara penanganan yang hampir sama dengan penanganan yang dilakukan oleh partisipan adalah dengan tidak meminum es dan mengkonsumsi minuman hangat. Remaja etnis Cina menganjurkan mengonsumsi minuman hangat yang mengandung gula karena dapat menurunkan nyeri menstruasi (22).

Gejala afektif adalah perubahan emosi kepada anak ibu memberikan respon yang beragam, mulai dari memahami yang anak alami dan ada pula ibu yang terbawa emosi dan ikut membalas kemarahan anak. Respon yang ibu berikan kepada anak menjadi hal pertama yang anak lakukan saat mengalami keluhan menstruasi. Penelitian menunjukkan remaja mengonsumsi minuman herbal sebagai salah satu cara untuk mengurangi nyeri perut (23).

Respon yang ibu berikan berkaitan dengan budaya yang ada. Respon individu berkaitan erat dengan lingkungan sosial budaya, sehingga akan memengaruhi sikap dan perilaku individu terhadap perilaku kesehatan (24). Bentuk respon yang ibu berikan pada anak merupakan bentuk dukungan yang diberikan oleh keluarga. Pertolongan dan saran ibu merupakan bentuk dukungan instrumental dan informasional, sedangkan ibu yang memahami perubahan emosi anak adalah bentuk dukungan emosional (25).

Penanganan ibu pada anak dengan keluhan menstruasi bersumber dari masa lalu. Ibu memiliki gejala fisik yang sama yang dialami oleh anak dan mengalami perubahan emosi sama seperti yang anak alami. Penyebab gejala belum dapat diketahui secara 
pasti, namun terdapat beberapa faktor predisposisi yang menyebabkan wanita mengalami gejala seperti faktor genetik. Remaja yang memiliki ibu dengan gejala pramenstrusi memiliki gejala lebih banyak dibanding remaja yang memiliki ibu dengan non gejala (26). Metode empirisme meyakini bahwa sumber dari pengetahuan berasal dari pengalaman yang diperoleh melalui panca indera manusia (27). Pengetahuan dari masa lalu diterapkan pada anak dengan gejala yang sama. Perlakukan orang tua terhadap anak sangat dipengaruhi oleh faktor pengala- man masa lalu (28).

\section{Ibu mencari informasi penanganan keluhan} menstruasi pada anak. Selain pengalaman sebagai sumber infromasi utama, ibu mendapatkan informasi dari berbagai sumber seperti keluarga, saudara kandung, teman, tenaga kesehatan seperti dokter dan media online. Penelitian ini menemukan informasi yang ibu dapatkan merupakan informasi yang kurang tepat, misal, Ibu mengetahui bahwa gejala fisik adalah akibat masuk angin.

Penyebab keluhan menstruasi memang belum diketahui secara pasti namun hal ini diduga berkaitan dengan kadar hormon estrogen dan progesteron dalam darah. Beberapa penelitian menemukan gejala pramenstruasi dikaitkan dengan kurang aktivitas fisik, pola makan, stres dan kurang asupan kalsium, vitamin B6 serta magnesium (29-31). Penelitian ini menemukan sumber informasi ibu dari tenaga kesehatan masih sangat minim, padahal informasi yang ibu dapatkan sangat memengaruhi penanganan dan informasi.

\section{SIMPULAN}

Ibu berperan penting dalam membantu anak mengahadapi gejala. ibu dapat memberikan dukungan, baik itu dukungan instrumental, penilaian, emosional dan informasional. Ibu harus memiliki pengetahuan yang memadai tentang gejala sehingga dukungan yang diberikan dapat maksimal.

\footnotetext{
Abstrak

Tujuan: Penelitian ini mengeksplorasi pengalaman ibu dalam menghadapi remaja dengan gejala premenstrual dysphoric disorder. Metode: Penelitian menggunakan metode kuantitaif dan kualitatif. Pada metode kuantitaif digunakan dengan rancangan cross-sectional dengan menggunakan kuesioner gejala PMDD sesuai DSM-IV pada remaja, sedangkan pada metode kualitatif menggunakan teknik wawan-
}

cara mendalam pada ibu dari remaja. Analisis data pada metode kuantitatif menggunakan analisis deskriptif sedangkan pada kualitatif menggunakan metode analisis data Colaizi (1973). Hasil: Terdapat 23 \% remaja mengalami gejala PMDD dan ditemukan lima tema 1) ibu mengetahui dan merasakan gejala PMDD yang dialami oleh anak, 2) Sikap dan keterbatasan waktu ibu dan anak memengaruhi tersampaikannya gejala PMDD anak kepada ibu, 3) Keberagaman respon ibu saat anak menghadapi gejala PMDD, 4) Penanganan yang ibu berikan kepada anak saat anak mengalami gejala PMDD bersumber dari masa lalu, 5) Ibu berusaha mencari informasi tentang penanganan yang dapat dilakukan saat mengalami gejala PMD. Simpulan: Ibu berperan penting dalam membantu anak menghadapi gejala PMDD. Ibu dapat memberikan dukungan, baik itu dukungan instrumental, penilaian, emosional dan informasional. Ibu harus memiliki pengetahuan yang memadai tentang gejala PMDD sehingga dukungan yang diberikan dapat maksimal.

Kata Kunci: peran ibu; remaja; premenstrual dysphoric disorder

\section{PUSTAKA}

1. Statistik BP. Provinsi Daerah Istimewa Yogyakarta Dalam Angka 2015. BPS Provinsi DI Yogyakarta. Yogyakarta. 2015.

2. Shiferaw MT, Wubshet M, Tegabu D. Menstrual problems and associated factors among students of Bahir Dar University, Amhara National Regional State, Ethiopia: A cross-sectional survey. The Pan African Medical Journal. 2014;17.

3. Qiao M, Zhang H, Liu H, Luo S, Wang T, Zhang J, Ji L. Prevalence of premenstrual syndrome and premenstrual dysphoric disorder in a population-based sample in China. European Journal of Obstetrics and Gynecology and Reproductive Biology. 2012 May 1;162(1):83-6.

4. Hamaideh SH, Al-Ashram SA, Al-Modallal H. Premenstrual syndrome and premenstrual dysphoric disorder among Jordanian women. Journal of psychiatric and mental health nursing. 2014 Feb 1;21(1):60-8.

5. Suparman, E. Premenstrual Sydrome. Jakarta: EGC. 2010.

6. Delara M, Ghofranipour F, Azadfallah P, Tavafian SS, Kazemnejad A, Montazeri A. Health related quality of life among adolescents with premenstrual disorders: a cross sectional study. Health and quality of life outcomes. 2012 Dec;10(1):1.

7. Hapsari ED, Mantani Y, Matsuo H. The Prevalence of Premenstrual Dysphoric Disorder and Its 
Modulation by Lifestyle and Psychological Factors in High School Students. Bulletin of health sciences Kobe. 2006:19-28.

8. Marfuah, D. Pengalaman Remaja yang Mengalami Gejala Premenstrual Dysphoric Disorder (PMDD) Pasca Erupsi Merapi: Studi Fenomenologi. Tesis Magister Keperawatan Universitas Gadjah Mada Yogyakarta. 2015.

9. Drosdzol A, Nowosielski K, Skrzypulec V, Plinta R. Premenstrual disorders in Polish adolescent girls: Prevalence and risk factors. Journal of Obstetrics and Gynaecology Research. 2011 Sep 1;37(9):1216-21.

10. Emilia S., Salmah A., Rahma. Perbandingan Usia Menars dan Pola Siklus antara Remaja Putri di Kota dan Desa (SMP Negeri 6 Makassar dan SMP Negeri 11 Bulukumba) di Sulawesi Selatan Tahun 2013. 2013. Diunduh dari repository.unhas.ac.id/bitstream/handle/12345678 9/6045/JURNAL\%20acc.pdf pada tanggal 20 Oktober 2016 pukul 13.45.

11. Parry B., Nowakowski., Martinez. Premenstrual Dysphoric Disorder in Hormone, Brain and Behaviour second edition. London: Academic Press Elsevier. 2009.

12. Mishra A, Banwari G, Yadav P. Premenstrual dysphoric disorder in medical students residing in hostel and its association with lifestyle factors. Industrial psychiatry journal. 2015 Jul;24(2):150.

13. Akyol, E.S. Ansoy E.O. Caykoylu.A. Anger in Women with Premenstrual Dysphoric Disorder: Its Relations With Premenstrual Dysphoric Disorder and Sociodemographic and Clinical Variables. Comprehensive Psychiatric , 2013.54, pp.850-855.

14. Speziale HS, Streubert HJ, Carpenter DR. Qualitative research in nursing: Advancing the humanistic imperative. Lippincott Williams \& Wilkins; 2011.

15. Farrokh-Eslamlou H, Oshnouei S, Heshmatian B, Akbari E. Premenstrual syndrome and quality of life in Iranian medical students. Sexual \& Reproductive Healthcare. 2015 Mar 1;6(1):23-7.

16. Nisar N, Zehra N, Haider G, Munir AA, Sohoo NA. Frequency, intensity and impact of premenstrual syndrome in medical students. J Coll Physicians Surg Pak. 2008 Aug 1;18(8):481-.

17. Sharma P, Malhotra C, Taneja DK, Saha R. Problems related to menstruation amongst adolescent girls. The Indian Journal of Pediatrics. 2008 Feb 1;75(2):125-9.

18. O'Connell K, Davis AR, Westhoff C. Self-treatment patterns among adolescent girls with dysmenorrhea. Journal of pediatric and adolescent gynecology. 2006 Aug 1;19(4):285-9.

19. Wilson EK, Dalberth BT, Koo HP. "We're the heroes!”: Fathers' perspectives on their role in protecting their preteenage children from sexual risk. Perspectives on sexual and reproductive health. 2010 Jun 1;42(2):117-24.

20. Anies D. Waspada Ancaman Penyakit Tidak Menular Solusi Pencegahan dari Aspek Perilaku dan Lingkungan. PT Elex Media Komputindo. 2006.

21. Putri, M. Proses Komunikasi Antar Pribadi dalam Keluarga Ibu Bekerja. 2014. diunduh dari http://jurnal.usu.ac.id/flow/article/viewfile/16792/7 084 pada tanggal 25 November 2017
22. Wong LP. Premenstrual syndrome and dysmenorrhea: urban-rural and multiethnic differences in perception, impacts, and treatment seeking. Journal of pediatric and adolescent gynecology. 2011 Oct 1;24(5):272-7.

23. Wong LP, Khoo EM. Dysmenorrhea in a multiethnic population of adolescent Asian girls. International Journal of Gynecology \& Obstetrics. 2010 Feb 1;108(2):139-42.

24. Noorkasiani., Heryati., Ismail, R. Sosiologi Keperawatan. Jakarta:EGC. 2009.

25. Harnilawati. Konsep dan Proses Keperawatan Keluarga.Sulawesi Selatan: Pustaka As Salam. 2013.

26. Rapkin AJ, Mikacich JA. Premenstrual dysphoric disorder and severe premenstrual syndrome in adolescents. Pediatric Drugs. 2013 Jun 1;15(3):191-202.

27. Soemowinoto, S. Pengantar Filsafat Ilmu Keperawatan. Jakarta: Salemba Medika. 2008.

28. Ermi, E. Pola Asuh Orang Tua: untuk Membantu Anak Mengembangkan Disiplin Diri. Indragiri Journal. Vol. 1 No 2 April. 2017. Diunduh dari journal.indragiri.com/index.php/jind/article/down load/11/8

29. Tambayong, J. Patofisiologi untuk Kesehatan. Jakarta: EGC. 2000.

30. Cahyanti, L. Hubungan Post Traumatic Stress Disorder dengan Prevalensi Premenstrual Syndrom dan Premenstrual Dysphoric Disorder pada Remaja Paska Bencana Merapi. Skripsi Strata Satu: Universitas Gadjah Mada Yogyakarta. 2012

31. Ramadani M. Premenstrual syndrome (PMS). Jurnal Kesehatan Masyarakat Andalas. 2012 Sep 1;7(1):21-5 